\title{
Efektivitas teknik mindfulness untuk mengatasi insomnia pada mahasiswa
}

\author{
Awidha Dwi Wijayaningsih ${ }^{1}$, Muhimmatul Hasanah ${ }^{2}$, dan Ima Fitri Sholichah ${ }^{3}$
}

\begin{abstract}
The goal of this study tested the effectiveness of Mindfulness training to overcome insomnia in college students. The number of participating subjects amounted to 8 people in the weight category, with four people in each group (experiment and control). Treatment was given to subjects in the experimental group as many as four meetings with 11 sessions within one month. For control is given a Mindfulness Diary to find out the emotional condition and sleep of the subject. The study used the Jakarta Psychiatric Study Group - Insomnia Rating Scale as a pre-test and posttest to measure insomnia levels before and after treatment. The data analysis technique used in the study was the Mann-Whitney U Test. The results showed that the experimental group's results $(\mathrm{Mdn}=7)$ were higher than those of the control group (Mdn=15.8). Mann-Whitney's test results showed a significant difference in pain scores between the experimental and control groups ( $\mathrm{N}$ experimen $=4$, Control $=4, \mathrm{Z}=-2,337 ; \mathrm{p}=0.019$ ). This can be seen in the decrease in insomnia score in the experimental group. Mindfulness training proved to be appropriate for overcoming insomnia in college students.
\end{abstract}

\section{Keywords}

Insomnia, mahasiswa, teknik mindfulness

\section{Pendahuluan}

Tidur merupakan kebutuhan dasar manusia. Normalnya durasi tidur pada manusia berlangsung selama 7-8 jam dalam sehari (Barlow \& Durand, 2015). Fungsi tidur adalah membantu memulihkan fungsi restoratif bagi tubuh sehingga apabila tidak terlaksana dapat memberikan dampak negatif yaitu mengalami gangguan tidur (Nevid et al., 2018). Namun demikian, untuk dapat tidur secara normal terkadang beberapa individu mengalami kendala sehingga tetap terjaga hingga larut. Kondisi kesulitan tidur dan tetap terjaga hingga larut tersebut dapat disebut dengan insomnia.

Menurut American Psychological Association (2015) insomnia yang memiliki nama lain Agrypnia adalah kesulitan dalam memulai atau mempertahankan tidur restoratif, yang mengakibatkan kelelahan yang parah atau terus-menerus menyebabkan tekanan yang signifikan secara klinis. (Susanti, 2015) menjelaskan terkait insomnia yang merupakan persepsi tidak adekuat dari kualitas tidur dan merupakan keluhan paling umum dari gangguan tidur, ditambahkan dalam (Nashori \& Wulandari, 2017) menyatakan bahwa kualitas tidur dapat digunakan sebagai tolak ukur individu mengalami tidur yang menghasilkan kesegaran dan kebugaran atau tidak saat terbangun. Menurut Sateia (2014), insomnia dapat ditegakkan apabila terdapat 1 atau lebih keluhan seperti yang terdapat pada ICSD-2, yaitu: kesulitan untuk memulai tidur, kesulitan untuk mempertahankan tidur sehingga sering terbangun dari tidur, bangun terlalu dini hari dan sulit untuk tidur kembali, tidur dengan kualitas yang buruk. Terdapat tambahan dalam ICSD-3, yaitu: durasi keluhan berlangsung selama 3 bulan, dan kriteria frekuensi terjadi kurang lebih 3 kali dalam seminggu Sateia (2014).

Insomnia merupakan gangguan tidur paling umum yang di alami oleh sebagian besar manusia di dunia. Insomnia dapat terjadi akibat otak yang memiliki struktur dan fungsi untuk mengatur tidur terganggu oleh stres, kecemasan, depresi dan sakit fisik. Menurut Nasution (2017) Insomnia dapat terjadi akibat zat yang dikeluarkan dan dilepaskan ke dalam darah sehingga membuat mengantuk, yang berasal dari pusat-pusat tidur yang mengatur siklus tidur dan terjaga terhambat oleh stres, kecemasan, gangguan, depresi, dan sakit fisik.

Menurut (National Institutes of Health, 2011) mengatakan bahwa sekitar $30 \%$ dari populasi orang di dunia mengeluhkan gangguan tidur, dan sekitar $10 \%$ mengeluhkan gejala terkait gangguan fungsi tubuh pada siang

\footnotetext{
1,3 Universitas Muhammadiyah Gresik, ${ }^{2}$ Institut Pesantren Sunan Drajat

Korespondensi:

Wijayaningsih, Program Studi Psikologi, Universitas Muhammadiyah Gresik

Email: awidha $70701 @ u m g . a c . i d$
} 
hari yang konsisten dengan indikasi diagnosis insomnia. Penelitian terkait yang dilakukan oleh National Sleep Foundation (NSF) pada survey tahun 2020, mendapatkan data bahwa $10 \%$ hingga $30 \%$ orang dewasa hidup dengan insomnia, 23,8\% terjadi pada remaja (Foley, 2020). insomnia juga dapat terjadi pada penduduk Indonesia. hasil penelitian menyebutkan prevalensi insomnia di Indonesia dilaporkan mencapai angka 28 juta orang atau $10 \%$ dari jumlah populasi pada tahun 2017. Angka ini masih tertinggi dibandingkan dengan negara di wilayah Asia lainnya (Salbiah, 2018).

Insomnia dapat terjadi pada siapa saja, termasuk kepada mahasiswa. Adanya variasi tugas dan kebiasaan yang berbeda dari jenjang pendidikan sebelumnya menyebabkan adanya pola tidur yang tidak teratur. Satrio et al. (2018) dan Taylor et al. (2011) mempertegas bahwa kelompok mahasiswa adalah kelompok yang rentan mengalami insomnia. Selain akibat dari pola tidur yang tidak teratur, insomnia ini juga bisa disebabkan oleh kecemasan, depresi, dan obsessive compulsive disorder yang dalami. Mendukung pernyataan tersebut Sathivel \& Setyawati (2017) menyebutkan bahwa umumnya mahasiswa mengalami insomnia batas ambang, klinis moderat, hingga klinis berat.

Semua mahasiswa dari berbagai prodi memiliki peluang yang sama untuk mengalami insomnia, termasuk mahasiswa fakultas psikologi. Sebuah riset menunjukkan data bahwa salah satu fakultas yang diteliti, mahasiswa psikologi merupakan salah satu yang paling banyak mengalami gejala insomnia (Nurdin et al., 2018). Berdasarkan preliminary study yang dilakukan pada program studi psikologi di perguruan tinggi $X$, beberapa mahasiswa mengeluhkan gejala insomnisa. Gejala insomnisa yang dirasakan begitu beragam yaitu pola tidur yang tidak teratur karena penundaan waktu tidur yang disengaja, ataupun pola tidur yang tidak teratur karena terpaksa menyelesaikan tugas dengan deadline yang singkat. Dampak yang dirasakan adalah terganggunya aktivitas di pagi harinya hingga stres yang dirasakan. Keluhan tersebut dilaporkan terjadi selama beberapa bulan. Kondisi pola tidur yang tidak teratur hingga berbulan-bulan lamanya tersebut menurut berbagai sumber dapat diklasifikasikan ke dalam karakteristik insomnia (American Psychiatric Association, 2013).

Untuk menangani insomnia, ada dua pendekatan yang dapat dilakukan yaitu pendekatan yaitu farmakologi dan non-farmakologi. Astuti (2013) mengatakan bahwa terapi farmakologi adalah terapi yang menggunakan obatobatan untuk mengatasi insomnia, diantaranya adalah Benzodiazepine dan Non-Benzodiazepine (Zaleplon, Zolpidem, Eszopiclone, dan sebagainya). Sedangkan, penyembuhan yang bersifat non-farmakologi yang dapat dilakukan, diantaranya adalah Cognitive Behavior Therapy (CBT) (McMain et al., 2015), relaksasi otot progresif (Hardani \& Putri, 2016), Islamic-Cognitive Behavioral Therapy (Nashori et al., 2020), Insomnia-Cognitive Behavioral Therapy (Nashori et al., 2019), dan Mindfulness (Gong et al., 2016). CBT adalah metode terapi yang dikembangkan oleh Aaron Beck yang bertujuan untuk mengubah distorsi kognitif untuk menghasilkan satu perilaku baru yang lebih adaptif (McMain et al., 2015). Relaksasi otot progresif adalah latihan relaksasi yang didahului dengan menegangkan tubuh secara sistematis dan kemudian merelaksasikan semua otot tubuh (Hardani \& Putri, 2016). Islamic-Cognitive Behavioral Therapy adalah terapi yang integrasi ajaran agama Islam dan berbasis pendekatan psikologi barat dengan memacu pada CBT, terapi ini berfokus untuk menangani depresi dengan menghilangkan pikiran negatif, irasional, dan tidak realistis (Nashori et al., 2020). insomnia-cognitive behavioral therapy terapi yang bertujuan untuk meningkatkan kesejahteraan subjektif individu dengan memacu kepada CBT (Nashori et al., 2019). Mindfulness adalah teknik yang menekankan pada pemfokusan perhatian pada peristiwa kekinian (peristiwa yang terjadi disini dan sekarang) (Greenberg, 2017). Mindfulness didefinisikan sebagai kesadaran yang timbul akibat kesengajaan untuk menyajikan dan menghadirkan pengalaman saat ini dengan cara yang tidak menghakimi dan menerima (Arbi \& Ambarini, 2018).

Teknik Mindfulness menurut Kabat-Zinn (2012) adalah kesadaran yang dikembangkan dengan memperhatikan dengan cara yang berkelanjutan dan mengkhususkan dengan sengaja, pada saat ini, dan tanpa menghakimi (KabatZinn, 2012). Berdasarkan penelitian yang dilakukan oleh Black et al. (2015) menemukan bahwa peserta dalam kelompok teknik Mindfulness menunjukkan signifikan peningkatan relatif terhadap peserta yang berada di kelompok sleep hygiene education (SHE) dengan alat ukur Pittsburgh Sleep Quality Index (PSQI), kelompok teknik Mindfulness menunjukkan peningkatan yang signifikan dibandingkan dengan kelompok SHE pada hasil kesehatan sekunder dari gejala insomnia, gejala depresi, gangguan kelelahan, dan kelelahan parah. Sejalan dengan hal tersebut, penelitian yang dilakukan oleh Wang et al. (2019) mendapatkan hasil bahwa dengan teknik Mindfulness terbukti menghasilkan peningkatan yang signifikan secara statistik dalam kualitas tidur dan pengurangan tingkat keparahan insomnia tetapi tidak terdapat efek signifikan pada indeks kuantitas tidur, yang diukur dengan catatan harian tidur atau tindakan objektif (Wang et al., 2019). Penelitian terdahulu, peneliti memilih menggunakan Mindfulness sebagai teknik untuk mengatasi insomnia pada mahasiswa dengan menggunakan kuesioner kelompok psikiatri biologi Jakarta- insomnia rating scale (KSPBJ-IRS) untuk mengukur tingkat insomnia yang di derita subjek sebelum diberi teknik Mindfulness dan setelah diberi teknik Mindfulness. Penggunaan kuesioner KSPBJ-IRS mengacu pada penelitian yang sejalan oleh Gudawati (2012) yang diujikan kepada lansia. Penggunaan kuesioner ini juga menjadi pembanding efektifitas terapi terhadap insomnia antara penelitian ini dengan penelitian yang telah dilakukan sebelumnya di tinjau dari segi usia dan metode terapi yang berbeda. 
Berdasarkan uraian diatas, tujuan penelitian ini untuk menguji efektivitas teknik Mindfulness untuk mengatasi insomnia yang terjadi pada mahasiswa. Peneliti memilih menggunakan teknik Mindfulness, yang lebih berfokus pada pemahaman dan penerimaan terhadap diri sendiri, dengan tidak adanya penghakiman terhadap pengalaman yang dialami dan lebih berfokus pada situasi dan kondisi disini dan saat ini sehingga berguna untuk meningkatkan disfungsional keyakinan terhadap tidur yang akhirnya berguna untuk mengatasi insomnia.

\section{Metode}

\section{Rancangan Penelitian}

Penelitian ini adalah kuantitatif berjenis eksperimen semu (quasi experiment design). Desain penelitian eksperimen semu ini merupakan eksperimen yang dilakukan tanpa randomisasi, namun masih melakukan pengontrolan terhadap variabel non-eksperimental dan masih menggunakan kelompok kontrol sebagai kelompok komparatif untuk memahami efek perlakuan (Latipun, 2015).

Penelitian ini menggunakan eksperimen semu dengan rancangan penelitian "non-equivalent control group design", merupakan pengukuran yang dilakukan sebelum (pratest) dan sesudah (pascatest) pemberian perlakuan pada kedua kelompok, dan pada desain ini sampel ditetapkan dengan tidak random (Latipun, 2015). Bentuk desain penelitian dalam penelitian ini dapat dilihat pada gambar 1 .

\section{Populasi dan Sampel}

Subjek penelitian ini adalah mahasiswa prodi psikologi di Universitas X angkatan 2016-2019 yang berjumlah 8 subjek ( $M=14, \mathrm{SD}=1,77$ ) yang semuanya berjenis kelamin perempuan dengan keluhan insomnia kategori berat. Ke-8 subjek penelitian tersebut bersedia terlibat secara aktif dalam proses penelitian dari awal hingga akhir dengan kesediaan mengisi informed consent. Jumlah subjek dalam penelitian ini memenuhi syarat pelaksanaan penelitian eksperimen, yaitu minimal 3-5 subjek pada setiap kelompok yang diteliti (kelompok kontrol dan kelompok perlakuan) (Alwi, 2015).

Pemilihan ke-8 subjek menggunakan teknik purposive sampling dengan kriteria sebjek penelitian sebagai berikut: (1) Subjek mengalami insomnia lebih dari 3 bulan (kategori berat), dengan ciri antara lain: kesulitan memulai

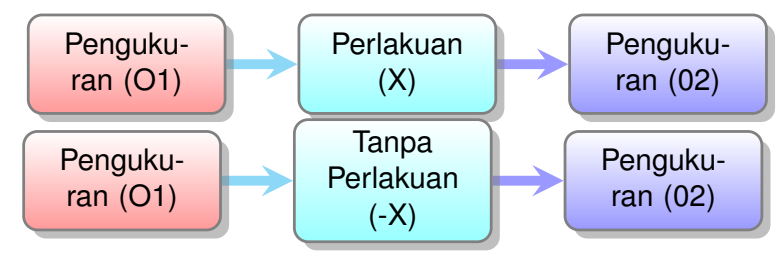

Gambar 1. Skema desain penelitian pada kelompok eksperimen (atas) dan kelompok kontrol (bawah) tidur, kesulitan mempertahankan tidur, ditandai dengan seringnya bangun atau masalah kembali tidur setelah bangun, bangun pada dini hari dengan ketidakmampuan untuk kembali tidur, kesulitan tidur terjadi setidaknya 3 malam per minggu, kesulitan tidur hadir setidaknya selama 3 bulan. (2) Subjek mengalami insomnia yang penyebabnya bukan hanya karena penggunaan gadget (handphone, tablet, laptop, dan sejenisnya) di malam hari menjelang waktu tidur, tetapi juga dikarenakan karena hal-hal emosional atau kejadian mental (seperti: kecemasan, stres, overthinking, dan sebagainya). (3) Bersedia mengikuti teknik dari awal hingga akhir dengan mengisi informed consent

\section{Instrumen Penelitian}

Teknik pengumpulan data pada penelitian ini menggunakan kuesioner sebagai instrumen utama dan wawancara, observasi serta hasil dokumentasi kegiatan. Pemberian kuesioner bertujuan untuk menilai kondisi level insomnisa yang diraskan subjek penelitian pra-tes dan pasca tes. Kuesioner yang digunakan adalah Kelompok Studi Psikiatri Biologi Jakarta- Insomnia Rating Scale (KSPBJ-IRS) yang telah diadaptasi. Kuesioner ini terdiri dari 8 pertanyaan yang sifatnya ordinal dengan tingkat validitas yang teruji antar psikiater dengan psikiater sebesar $\mathrm{r}=0,95$ dan uji antar psikiater dengan dokter non psikiater $\mathrm{r}=0,94$, dan nilai koefisien uji reliabilitas sebesar 0,891 (Waliyanti \& Pratiwi, 2017). Hasil skoring tiap aitem dapat dikategorikan sebagai: Tidak ada keluhan insomnia $(<8)$, Insomnia ringan (8-12), Insomnia berat (8-12), dan Insomnia sangat berat $(>18)$.

Responden dinyatakan insomnia apabila hasil skor KSPBJ-IRS yang diperoleh $\geqslant 8$ dan dinyatakan tidak insomnia apabila hasil skor KSPBJ-IRSyang diperoleh $<$ 8 (Premani et al., 2017).

Selanjutnya data hasil wawancara dan observasi digunakan sebagai sarana untuk melihat efek dari pemberian teknik Mindfulness di setiap sesinya. Dokumentasi kegiatan digunakan untuk mengetahui gambaran apa yang terjadi pada subjek penelitian selama sesi intervensi terkait masalah tidur dan emosi yang dirasakan (Munazilah \& Hasanat, 2018).

\section{Analisis Data}

Analisis data dalam penelitian menggunakan analisis kuantitatif berupa penggunaan analisis statistik uji $U$ Mann-Whitney. Santoso (2018) mengatakan uji U MannWhitney digunakan untuk menguji variabel independen, yang berjumlah dua sampel, dan keduanya tidak berhubungan satu dengan lainnya, dan dengan bantuan program aplikasi komputer Statistical Packages for Social Sciences (SPSS) 22.0 for windows. Analisis kualitatif dilakukan dengan meninjau Diary Mindfulness subjek penelitian dalam sebulan, yang dibagikan tiap satu minggu setelah subjek diberikan perlakuan. 


\section{Prosedur Eksperimen}

Ada beberapa tahapan yang dilakukan dalam melakukan intervensi pada penelitian eksperimen ini yaitu: (1) Melakukan adaptasi modul teknik Mindfulness yang dikembangkan Vinny (2014) dan Kabat-Zinn (2013)2014. Proses adaptasi dilakukan dengan melibatkan dua orang professional judgement yang berprofesi sebagai psikolog dan dosen di bidang psikologi. (2) Subjek diberikan textitpratest untuk mengetahui kondisi awal dan data digunakan sebagai dasar penentuan kelompok kontrol (4 orang) dan kelompok eksperimen (4 orang). Kelompok eksperimen diberikan teknik Mindfulness selama 4 kali pertemuan dengan 11 sesi, per sesinya berlangsung selama 20 menit. Sedangkan kelompok kontrol tidak mendapatkan perlakuan. Secara terperinci aktivitas pemberian Mindfulness dapat dilihat pada Tabel 1. (3) Intervensi yang dilakukan kepada subjek penelitian dilakukan sebanyak 4 kali pertemuan dengan 11 sesi (Munazilah \& Hasanat, 2018). Adapun fasilitator yang dilibatkan adalah seorang psikolog klinis anak dan dewasa yang bekerja di Lembaga Psikologi X di Gresik, Jawa Timur. Secara umum intervensi yang diberikan hanya menggunakan 6 dari 9 teknik yang telah dirumuskan, yaitu: you have only moments to live, the power of breathing, the foundations of Mindfulness practice: attitudes and commitment, being in your body: the body scan technique, a day of Mindfulness, dan really doing what you're doing: Mindfulness in daily activity. (4) Pemberian pascatest, untuk melihat efektivitas teknik Mindfulness yang diberikan.

\section{Hasil \\ Deskripsi Data Penelitian}

Terdapat penurunan skor antara prates (Mean=13,75) dan pascates $(M e a n=7)$ pada kelompok eksperimen dan tidak ada penurunan skor antara prates (Mean=14) dan pascates $($ Mean $=15,8)$ pada kelompok kontrol. Artinya ada perubahan skor pada kelompok eksperimen yang mengindikasikan bahwa ada pengaruh pemberian teknik Mindfulness terhadap penurunan insomnisa yang dialami oleh subjek penelitian. Sedangkan pada kelompok kontrol tidak mengalami perubahan.

Hal ini sesuai dengan data yang diperoleh dari uji hipotesis, bahwa ditemukan adanya perbedaan signifikansi antara selisih nilai prates dan pascates pada kelompok eksperimen $(\mathrm{Mdn}=7)$ dan kelompok kontrol $(\mathrm{Mdn}=15.8)$ dengan nilai $\mathrm{Z}=-2.337$; dan $\mathrm{p}=0.019$ (taraf signifikansi 5\%). Artinya, teknik Mindfulness berpengaruh terhadap penurunan insomnia yang dirasakan oleh kelompok eksperimen. Selanjutnya secara terperinci, penurunan tingkat insomnia pada responden penelitian dapat dilihat pada Tabel 2.

Pada Tabel 2 menjelaskan bahwa ada penurunan tingkat insomnia pada empat orang responden penelitian pada kelompok eksperimen dimana secara umum dari gejala berat berangsur mengalami penurunan menjadi gelaja

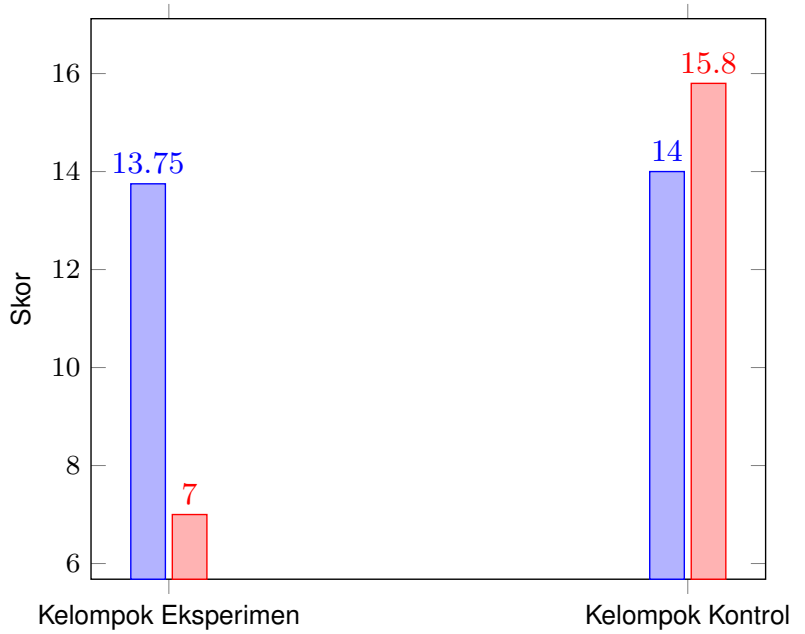

Gambar 2. Grafik skor rata-rata kelompok eksperimen dan kelompok kontrol

ringan bahkan hingga tidak ada. Kondisi ini berbeda pada subjek kelompok kontrol yang tidak mengalami perubahan gejala insomnisa karena tidak adanya perlakuan yaitu pemberian teknik Mindfulness.

\section{Data Kualitatif}

Pertemuan pertama terapis mewawancarai subjek pada kelompok eksperimen terkait insomnia yang di derita. Subjek mengeluhkan mengalami insomnia semenjak menjadi mahasiswa, dikarenakan tuntutan mengerjakan tugas yang akhirnya menunda untuk tidur, dan hal tersebut berlanjut hingga sekarang. Subjek mengeluhkan baru bisa tidur selalu diatas pukul 12 malam, dan ketika bangun keesokan harinya mereka merasa kelelahan dan tidak segar.

Pertemuan kedua subjek masih mengeluhkan mengalami insomnia yang tidak berubah dari minggu sebelumnya. Di tinjau dari Diary Mindfulness yang telah mereka tulis mereka masih tidur di atas jam 12 malam dan ketika bangun badan merasa lelah. Pelakukan pertemuan kedua ini dimulai dengan posisi peneliti dan terapis berada si samping kanan subjek karena agar tidak mengganggu konsentrasi dan fokus subjek selama teknik. Pada teknik pertemuan kedua ini dilakukan 3 sesi Mindfulness yaitu sesi you have only moments to live, the power of breathing, dan the body scan technique. Di setiap sesi dilakukan selama 20 menit, dengan pengarahan oleh terapis 8-15 menit di setiap sesinya di lanjutkan dengan membahas manfaat teknik-teknik dalam setiap sesi dan juga perasaan yang di rasakan subjek ketika telah melakukan teknik di setiap sesi. Berikut ini perilaku subjek yang muncul selama penelitian berlangsung berdasarkan hasil observasi yang diperoleh setiap sesinya selama 8-15 menit, yaitu berusaha fokus, mengernyitkan dahi, rileks, membetulkan posisi kerudung, menggaruk kepala, duduk bersandar ke dinding, menarik nafas, mengangkat kepala ketika menarik nafas dalam, merubah posisi duduk. 
Tabel 1. Jadwal Teknik Mindfulness

\begin{tabular}{|c|c|c|c|}
\hline Pertemuan & Sesi & Kegiatan & Durasi \\
\hline \multirow{4}{*}{ I } & I & Pembukaan, Prates, Absensi Subjek & 20 Menit \\
\hline & II & Pohon Harapan & 20 Menit \\
\hline & III & Pengantar Mindfulness & 20 Menit \\
\hline & IV & Materi You Have Only Moments To Live. & 20 Menit \\
\hline \multirow[t]{2}{*}{ II } & $\mathrm{V}$ & Materi The Power Of Breathing & 20 Menit \\
\hline & VI & Materi Being In Your Body: The Body Scan Technique. & 20 Menit \\
\hline \multirow[t]{3}{*}{ III } & VII & $\begin{array}{l}\text { Materi The Foundations Of Mindfulness Practice: Attitudes And Commitment (non } \\
\text { judging, patience, beginner's mind, trust). }\end{array}$ & 30 Menit \\
\hline & VIII & $\begin{array}{l}\text { Materi The Foundations Of Mindfulness Practice: Attitudes And Commitment (non- } \\
\text { striving, acceptance, letting go). }\end{array}$ & 30 Menit \\
\hline & $\mathrm{IX}$ & Materi A Day Of Mindfulness & 20 Menit \\
\hline \multirow[t]{2}{*}{ IV } & $\mathrm{X}$ & $\begin{array}{l}\text { Materi Really Doing What You're Doing: Mindfulness in Daily Activity dan diakhiri } \\
\text { Pascates. }\end{array}$ & 20 Menit \\
\hline & $\mathrm{XI}$ & Penutup dan Pemberian Kenang-kenangan. & 24 Menit \\
\hline
\end{tabular}

Tabel 2. Tingkat Insomnia Pratest dan Pascatest Subjek pada Kelompok Eksperimen dan Kelompok Kontrol

\begin{tabular}{llllll}
\hline & \multicolumn{2}{l}{ Kelompok Eksperimen } & & \multicolumn{2}{l}{ Kelompok Kontrol } \\
\cline { 2 - 3 } \cline { 6 - 6 } Subjek & Prates & Pascates & & Prates & Pascates \\
\hline 1. & $13($ Berat) & $5(\mathrm{TA})$ & & $13(\mathrm{~B})$ & $13(\mathrm{~B})$ \\
2. & $15(\mathrm{~B})$ & $9(\mathrm{R})$ & & $16(\mathrm{~B})$ & $19(\mathrm{SB})$ \\
3. & $13(\mathrm{~B})$ & $6(\mathrm{TA})$ & & $14(\mathrm{~B})$ & $15(\mathrm{~B})$ \\
4. & $14(\mathrm{~B})$ & $8(\mathrm{R})$ & & $14(\mathrm{~B})$ & $14(\mathrm{~B})$ \\
\hline
\end{tabular}

Keterangan

SB = Sangat Berat; $B$ = Berat; $\mathrm{R}$ = Ringan; $\mathrm{TA}$ = Tidak ada

Pertemuan ketiga subjek menceritakan sudah mulai bisa tidur dengan lebih baik di bandingkan minggu-minggu sebelumnya, tidur paling malam jam 12, dan jarang mimpi buruk serta terbangun. Pada pertemuan ini dilakukan 2 sesi Mindfulness yaitu sesi non judging; patience; beginner's mind; trust dan non-striving; acceptance; letting go. Di setiap sesi dilakukan selama 20 menit, dengan pengarahan oleh terapis 10-15 menit di setiap sesinya di lanjutkan dengan membahas manfaat teknikteknik dalam setiap sesi dan juga perasaan yang di rasakan subjek ketika telah melakukan teknik di setiap sesi. Hasil observasi yang di peroleh setiap sesinya selama 10-15 menit tersebut, berikut ini perilaku subjek yang muncul selama penelitian berlangsung yaitu rileks, fokus, bermain jari, mengusap punggung tangan, menggaruk hidung dan telinga, menggoyangkan telapak kaki, dan mengusap mata.

Pertemuan keempat ini dilakukan 3 sesi Mindfulness yaitu sesi a day full of Mindfulness (meditasi makan), Mindfulness in Daily, dan penutup. Di setiap sesi dilakukan selama 20 menit, dengan pengarahan oleh terapis 5-10 menit di setiap sesinya di lanjutkan dengan membahas manfaat teknik-teknik dalam setiap sesi dan juga perasaan yang di rasakan subjek ketika telah melakukan teknik di setiap sesi. Pada sesi A Day Full of Mindfulness (meditasi makan), peneliti menyediakan kismis dan kurma, karena mempertimbangkan jika terdapat subjek tidak menyukai salah satu dari makanan tersebut bisa melakukan meditasi makan dengan makanan yang satunya. Dari hasil observasi yang di peroleh setiap sesinya selama 10-15 menit tersebut, berikut ini perilaku subjek yang muncul selama penelitian berlangsung yaitu subjek 1, 3, dan 4 mengambil kurma dan subjek 2 mengambil kismis, merasakan tekstur kismis dan kurma, memejamkan mata, fokus pada makanan, dan makan dengan perlahan. Untuk sesi Mindfulness in Daily berikut adalah perilaku yang muncul selama penelitian berlangsung yaitu mendengarkan pertanyaan, menuliskan jawaban pada kertas, berdiam diri selama beberapa detik dengan menengadahkan wajah ke arah atas lalu menuliskan jawabannya, dan membaca kembali tulisannya. Pada sesi Mindfulness in Daily, subjek diberikan selembar kertas untuk menuliskan jawaban-jawabannya terkait pertanyaan yang dikemukakan pada sesi X, setelah itu terapis meminta subjek untuk membacakan hasil buah pemikiran subjek dari pertanyaan-pertanyaan pada sesi X.

Setelah terapi berakhir, peneliti melakukan follow up terhadap subjek-subjek kelompok eksperimen, dan hasilnya para subjek merasakan lebih rileks dan tenang karena bisa mengontrol diri dalam hal waktu, pikiran, dan perasaan setelah mengikuti teknik ini, dan juga 2 orang subjek telah berhasil mengatasi insomnianya sehingga bisa tidur di jam yang normal, 2 orang lainnya bisa tidur lebih awal daripada sebelum mengikuti teknik Mindfulness ini. Dari hasil follow up terhadap subjek ini, dapat disimpulkan bahwa, terdapat efektivitas teknik Mindfulness untuk mengatasi insomnia pada mahasiswa di kelompok eksperimen.

\section{Diskusi}

Berdasarkan hasil analisis data kuantitatif dan kualitatif menunjukkan bahwa terdapat perbedaan yang signifikan antara kelompok eksperimen dan kelompok kontrol, dalam hal insomnia yang dialami oleh mereka. Hipotesis dalam penelitian ini adalah terdapat efektivitas dari teknik Mindfulness untuk mengatasi insomnia pada mahasiswa prodi Psikologi Universitas X angkatan 20162019 diterima. Analisis data menunjukkan bahwa sebelum diberi perlakuan, kelompok eksperimen dan kelompok 
kontrol memiliki tingkat insomnia yang sama. Setelah diberi perlakuan, terdapat perbedaan antara kelompok eksperimen dan kelompok kontrol. Adapun dilihat hasil gain score, mendapati bahwa terdapat perbedaan yang signifikan tingkat insomnia antara kelompok eksperimen dan kelompok kontrol. Kondisi tersebut memiliki kesimpulan bahwa teknik Mindfulness efektif dalam mengatasi insomnia pada mahasiswa.

Berdasarkan hasil yang telah dilakukan pada penelitian ini, hasilnya mendukung teori yang dikemukakan pada penelitian oleh Gong et al. (2016) yang menyatakan bahwa hasil meta-analysis menggambarkan bahwa Mindfulness berkontribusi dalam meningkatkan tidur, yang di tinjau dari kualitas tidur dan efisiensi tidur. Hasil analisis statistik di atas sejalan dengan hasil analisis data individu yang menunjukkan terdapat manfaat teknik Mindfulness dalam mengatasi insomnia. Insomnia dapat terjadi karena faktorfaktor psikologis (Nevid et al., 2018) yang diantaranya adalah perubahan situasi belajar, stres, overthinking, dan kecemasan. Perubahan situasi yang dihadapi mahasiswa akan menjadi stressor yang memicu perubahan emosional dan perilaku, gangguan tersebut juga akan memberikan pengaruh pada fungsi sosial dan kognitif individu (Gunanthi \& Diniari, 2016). Pada perubahan situasi belajar ini terjadi pada subjek 1 yang menceritakan bahwa mulai mengalami insomnia sejak kuliah daring (pada bulan Maret) dan subjek 3 yang juga harus menyesuaikan diri dengan bekerja, kuliah, dan mengerjakan tugas. Pada subjek 2 dan subjek 4, mengalami insomnia karena stres tugas dan overthinking sehingga mengalami kecemasan dan berujung insomnia.

Teknik Mindfulness dalam penelitian ini membantu subjek dalam mengatasi insomnia karena kecemasan dan stres dengan membantu subjek untuk lebih rileks, tenang dan nyaman terhadap segala sesuatu yang terjadi, sehingga dapat menurunkan perasaan cemas dan stres. Hal ini sejalan dengan penelitian yang dilakukan Keng et al. (2011) mengungkapkan bahwa teknik Mindfulness memiliki berbagai efek positif terhadap psikologis, termasuk meningkatkan kesejahteraan subjektif, penurunan gejala psikologis dan reaksi emosional, serta meningkatkan regulasi perilaku.

Poin penting dalam Mindfulness adalah disini dan saat ini (here and now) sebagai landasan yang menjadi efek dari teknik Mindfulness dapat mengatasi insomnia pada mahasiswa. Dijelaskan oleh Greenberg (2017) bahwa Mindfulness menekankan pada pemfokusan perhatian pada peristiwa kekinian (peristiwa yang terjadi saat ini). Pemfokusan perhatian disini dan saat ini menjadikan subjek menjadi rileks, lebih merasa bahagia, dan ketika bangun tidur subjek merasa lebih segar. Perasaanperasaan yang dialami subjek tersebut berbeda dengan perasaan yang dialami subjek sebelum mendapatkan teknik Mindfulness, yaitu perasaan cemas, stres, dan ketika bangun tidur mengalami perasaan tidak segar. Hal ini sejalan dengan yang dikemukakan oleh Hubbling et al. (2014) yang mengatakan bahwa subjek yang mengalami peningkatan dalam tidur dan berdampak positif pada kehidupan mereka, mereka menyadari hubungan yang kuat antara melakukan teknik-teknik Mindfulness dengan regulasi emosi.

Perubahan yang dialami subjek sebagian besar terjadi pada bertambahnya kuantitas tidur, kualitas tidur, dan sleep hygiene yang membaik pada masing-masing subjek. Subjek merasa setelah diberi perlakuan jam tidurnya dapat lebih lama (yaitu berkisar antara 5 jam 30 menit hingga lebih dari 6,5 jam), lalu kualitas tidur yang dapat tidur dalam dan tidak mudah terbangun, dan juga tidak terdapat mimpi dan bangun terasa segar, subjek juga menceritakan bahwa kesulitan untuk masuk tidur setelah teknik hanya berkisar 6-30 menit. Perubahan-perubahan yang dialami subjek ini sejalan dengan yang dikemukakan KabatZinn (2013) bahwa penerimaan dan Mindfulness dapat membantu mengubah keyakinan yang buruk terhadap tidur, meningkatkan kesadaran akan kebiasaan sleep hygiene yang buruk, dan mencegah perilaku kontraproduktif dari berusaha keras untuk tidur.

Subjek menceritakan bahwa setelah diberikan teknik Mindfulness, subjek lebih tenang, bahagia dan tidak lagi mengalami stres. Ketika teknik Mindfulness subjek yang diberikan petunjuk untuk melakukan teknik pernafasan (the power of breathing) yang memiliki tujuan memberi kemampuan kepada subjek untuk tenang dengan memperhatikan dan memahami udara yang masuk dan keluar dari dalam tubuhnya dalam beberapa waktu (Kabat-Zinn, 2013), yang akhirnya dapat membantu subjek untuk memiliki kesadaran memikirkan yang terjadi saat ini dalam dirinya. Sehingga ketika berhasil untuk memfokuskan diri pada saat ini, secara tidak langsung subjek akan mendapati pemikiran baru pada saat ini untuk memecahkan masalah yang dihadapi. Sejalan dengan yang dikemukakan oleh Burg et al. (2012) dalam penelitiannya mendapatkan hasil bahwa yang mengatakan bahwa latihan pernafasan akan meningkatkan kesadaran sehingga meningkat juga regulasi diri individu dalam mengatasi kecemasan yang berasal dari pemikiran tentang emosi negatif individu tersebut. Ditambahkan oleh Carter \& Carter (2016) bahwa latihan pernafasan memiliki banyak bukti seperti peningkatan kinerja kognitif, perfusi jaringan yang lebih baik, menurunkan tekanan darah, metabolisme glukosa, dan meningkatkan sistem kekebalan tubuh, sehingga meningkatnya kinerja individu.

Subjek menceritakan bahwa sekarang merasa lebih bahagia, karena sudah dapat mulai merencanakan apa yang akan dilakukan dan tidak perlu berfikiran overthinking terhadap apapun dan juga permasalahan-permasalahan yang mengganggu dari masa lalu maupun pemikiran masa depan, hal ini dapat terjadi karena teknik Mindfulness memiliki fungsi untuk membantu individu berusaha untuk memahami perasaan, emosi, dan pengalaman individu tanpa bereaksi pada hal-hal tersebut (Brand et al., 2012). Subjek juga tidak memaksakan diri untuk 
gelisah dan takut terhadap perkuliahan maupun tugastugasnya. Subjek juga mulai menghadapi permasalahanpermasalahan yang sedang dihadapi dari berbagai sudut pandang. Teknik Mindfulness pada teknik attitudes and commitment, membantu subjek untuk mendapatkan pemikiran-pemikiran baru dengan melakukan penerimaan terhadap pengalaman dan berada di masa saat ini. Juga melakukan perilaku letting go dengan membiarkan segalanya terjadi apa adanya.

Faktor-faktor yang mempengaruhi Mindfulness seperti niat, perhatian, dan sikap membuat subjek dapat mengalami perubahan dari segi fisik maupun psikologis. Perubahan tersebut berdampak dalam menurunnya insomnia yang di derita subjek dalam kelompok eksperimen. Faktor-faktor tersebut harus dimiliki dan ditekankan kepada setiap subjek yang menjalani teknik Mindfulness, karena faktor-faktor tersebut yang mempengaruhi berhasil atau tidaknya teknik Mindfulness, seperti yang di kemukakan oleh Shapiro \& Carlson (2017) bahwa niat, perhatian, dan sikap saling berhubungan satu sama lain, dan ketiga hal inilah yang menjadikan teknik Mindfuness menikmati proses momen-ke-momen.

Subjek-subjek dalam penelitian ini memiliki kategori skor pascates akhir insomnia yang berbeda. 2 subjek memiliki kategori tidak mengalami insomnia, yaitu subjek 1 dan 3. 2 subjek lainnya, yaitu subjek 2 dan 4 memiliki kategori insomnia ringan. Hal ini disebabkan karena subjek 1 dan 2 memiliki skor pratest yaitu 13, yang merupakan skor di kategori berat paling rendah. Sedangkan 2 subjek lainnya yang berada pada kategori ringan memiliki skor pratest 15 dan 14. Faktor lain yang dapat menyebabkan tingkat insomnia menjadi ringan atau tidak ada insomnia sama sekali karena waktu teknik. Pada teknik ini menggunakan 4 kali pertemuan selama 1 bulan, dan berfungsi untuk mengatasi insomnia dari kategori yang tinggi (berat) menjadi kategori yang rendah (ringan atau tidak sama sekali). Sejalan dengan hal tersebut, penelitian yang dilakukan oleh Bjornsdottir et al. (2015) mendapatkan hasil bahwa subjek memperlihatkan kualitas tidur mengalami peningkatan dan penurunan gangguan tidur. Pada subjek yang masih mengalami insomnia kategori ringan mungkin memerlukan penambahan pertemuan teknik Mindfulness menjadi 8 minggu. Teknik Mindfulness 8 minggu, memiliki fungsi untuk menghilangkan insomnia yang dialami oleh individu dengan menghilangkan gangguangangguan tidur, hal tersebut sejalan dengan penelitian yang dilakukan oleh Larouche et al. (2015) yang mendapatkan hasil subjek-subjek penelitian mengalami peningkatan sleep efficacy, bangun lebih awal dan bangun di malam hari menurun, serta hal-hal tersebut bertahan hingga 3 bulan dengan peningkatan signifikan dalam kualitas tidur, bangun pagi hari, dan total waktu tidur.

Secara keseluruhan, teknik Mindfulness terbukti memberikan efek rileks, tenang dan membantu individu untuk dapat memiliki pikiran mindful. Subjek penelitian merasakan rileks, tenang, nyaman, dan lebih bahagia serta tidak lagi overthinking, stres, dan cemas. Sehingga dapat mengatasi individu yang mengalami insomnia karena kejadian mental tersebut, untuk tidak lagi mengalami insomnia karena telah dapat untuk rileks, tenang, dan berfikiran mindful. Sejalan dengan yang dikemukakan oleh Khoury et al. (2013) teknik Mindfulness memiliki bukti kuat sebagai teknik yang efektif berbagai masalah psikologis termasuk kecemasan, depresi, dan stres. Hal ini sejalan dengan yang dikemukakan Pillay \& Eagle (2019) bahwa efek teknik Mindfulness meliputi neurologis, somatik, kognitif, sikap, interpersonal, dan dimensi eksistensial yang memiliki hubungan dengan kondisi stres traumatis.

Beberapa teknik pada teknik Mindfulness ini dapat diterapkan untuk materi beberapa mata kuliah, seperti teknik pernafasan, teknik you have moments to live, dan teknik attitudes and commitment. Ketiga teknik itu dapat diterapkan pada mata kuliah seperti Kesehatan Mental, Psikoterapi, dan Konseling. Memberikan beberapa materi Mindfulness kepada mahasiswa dapat membantu mahasiswa dalam berpikiran positif, dan membantu mahasiswa untuk menurunkan stres dan cemas selama menempuh perkuliahan.

Kendala-kendala dalam penelitian ini adalah: (1) Kendala teknis, yaitu tempat yang kurang kondusif karena terdapat gangguan yang muncul secara tibatiba, gangguan tersebut dapat berupa suara motor dan pintu tertutup, (2) subjek intervensi yang kurang bisa mengontrol fokus saat intervensi, karena beberapa menceritakan masih overthinking dengan masalah-masalah yang tengah di hadapi, (3) pengontrolan penelitian ini hanya menggunakan buku diary Mindfulness, yang hanya menggambarkan kuantitas, kualitas tidur, serta perasaan subjek di setiap harinya setelah mengikuti teknik Mindfulness, sehingga untuk mengukur aktivitas otak saat subjek tidur tidak diketahui. Penggunaan electroencephalograph (EEG) dapat membantu dalam mengukur aktivitas otak subjek, sehingga lebih tergambar spesifik efek dari teknik Mindfulness.

Penelitian ini memiliki batasan dalam menggeneralisasikan hasil penelitian yang digunakan sebagai pertimbangan penelitian selanjutnya, diantaranya adalah: (1) penelitian ini hanya berbatas pada mahasiswa yang mengalami insomnia pada kategori berat, sehingga belum di ketahui jika dilakukan pada mahasiswa yang mengalami insomnia pada kategori ringan dan kategori sangat berat, (2) penelitian ini hanya berbatas pada mahasiswa yang mengalami kejadian mental (seperti: stres dan kecemasan), sehingga tidak diketahui efektivitas Mindfulness pada mahasiswa yang mengalami insomnia selain karena kejadian mental (seperti: merokok dan penggunaan handphone), penelitian ini hanya berbatas pada penggunaan 6 dari 9 teknik Mindfulness, sehingga belum diketahui jika dilakukan dengan ke-9 teknik apakah akan lebih memberikan efek dalam mengatasi insomnia, (3) pada penelitian ini hanya menggunakan 4 kali pertemuan.

Berdasarkan beberapa pendapat dan penelitianpenelitian terkait Mindfulness dalam mengatasi insomnia 
yang telah dilakukan sebelumnya serta hasil penelitian yang telah dilakukan, terbukti bahwa Mindfulness mempunyai banyak manfaat terhadap individu dan dapat digunakan dalam mengatasi insomnia termasuk pada mahasiswa.

\section{Kesimpulan}

Berdasarkan hasil penelitian yang telah dijabarkan sebelumnya, dapat ditarik kesimpulan bahwa teknik Mindfulness dapat mengatasi insomnia pada mahasiswa. Hal ini dapat diketahui dengan uji $U$ mann-whitney, bahwa nilai signifikansi yang diperoleh nilai signifikansi lebih kecil dari nilai probablitas. Jika ditinjau dari gain score nilai prates dan pascates kelompok eksperimen dan kelompok kontrol, dapat diketahui bahwa nilai signifikansi yang diperoleh juga lebih kecil dari nilai probabilitas. Artinya bahwa terdapat efektivitas teknik Mindfulness untuk mengatasi insomnia pada mahasiswa, sehingga hipotesis diterima. Hasil tersebut, menunjukkan bahwa efektivitas teknik Mindfulness untuk mengatasi insomnia pada mahasiswa prodi Psikologi Universitas X angkatan 2016-2019 telah terbukti.

\section{Saran}

Bagi penelitian selanjutnya yang ingin menggunakan teknik Mindfulness juga, sebaiknya peneliti terlebih dahulu mengatasi kendala-kendala yang sudah dijelaskan dalam penelitian ini.Jika memungkinkan sebaiknya peneliti mengukur kondisi tidur dengan electroencephalograph (EEG) yaitu alat untuk mengukur aktivitas otak dengan penggunaan alat laboratorium.

\section{Referensi}

Alwi, I. (2015). Kriteria empirik dalam menentukan ukuran sampel pada pengujian hipotesis dan analisis butir. Jurnal Formatif, 2(2). 140-148. http://dx.doi.org/10.30998/formatif. v2i2.95

American Psychiatric Association. (2013). Diagnostic and statistical manual of mental disorders (5th ed.). Washington: American Psychiatric Publishing.

American Psychological Association. (2015). APA dictionary of psychology (2nd ed.). Washington: American Psychological Association.

Arbi, D. K., \& Ambarini, T. K. (2018). Terapi brief mindfulnessbased body scan untuk menurunkan stres atlet bola basket. Jurnal Psikologi dan Kesehatan Mental, 3(1). 1-12. http: //dx.doi.org/10.20473/jpkm.V3I12018.1-12

Astuti, N. H. (2013). Penatalaksanaan insomnia pada usia lanjut. E-Jurnal Medika Udayana, 2(4), 736-750. https://ojs.unud. ac.id/index.php/eum/article/view/5119.

Azwar, S. (2013). Penyusunan skala psikologi. Yogyakarta: Pustaka Pelajar.

Barlow, D. H., \& Durand, M. V. (2015). Abnormal psychology: An integrative approach. Canada: Cengage Learning.
Bjornsdottir, S. V., Arnljotsdottir, M., Tomasson, G., Triebel, J., \& Valdimarsdottir, U. A. (2015). Health-related quality of life improvements among women with chronic pain: comparison of two multidisciplinary interventions. Disability and Rehabilitation, 1(9). http://10.3109/09638288.2015. 1061609

Black, D. S., O’Reilly, G. A., Olmstead, R., Breen, E. C., \& Irwin, M. R. (2015). Mindfulness meditation and improvement in sleep quality and daytime impairment among older adults with sleep disturbances. JAMA Internal Medicine, 1-8. https: //doi.org/10.1001/jamainternmed.2014.8081.

Brand, S., Trachsler, Edith H., Naranjo, Jose R., \& Schmidt, S. (2012). Influence of mindfulness practice on cortisol and sleep in long-term and short-term meditators. Neuropsychobiology. 6(5). 109-118. https://doi.org/10.1159/ 000330362

Burg, J. M., Wolf, O. T., \& Michalak, J. (2012). Mindfulness as self-regulated attention: Associations with heart rate variability. Swiss Journal of Psychology, 71(3), 135-139. https://doi.org/10.1024/1421-0185/a000080

Carter, K. S., \& Carter, R. (2016). Breath-based meditation: A mechanism to restore the physiological and cognitive reserves for optimal human performance. World journal of clinical cases, 4(4), 99-102. https://doi.org/10.12998/wjcc. v4.i4.99

Foley, L. (2020). Insomnia: What it is, how it affects you, and how to help you get back your restful nights. https://www. sleepfoundation.org/sleep-disorders/insomnia

Greenberg, J. S. (2017). Comprehensive Stress Management. New York: Mc Graw-Hill.

Gong, H., Ni, C.-X., Liu, Y.-Z., Zhang, Y., Su, W.-J., Lian, Y.-J., . . . Jiang, C.-L. (2016). Mindfulness meditation for insomnia: A meta-analysis of randomized controlled trials. Journal of Psychosomatic Research, 8(9), 1-6. http://10. 1016/j.jpsychores.2016.07.016

Gudawati, L. (2012). Perbedaan Tingkat Insomnia Lansia Sebelum Dan Sesudah Latihan Senam Yoga Di Posyandu Lansia Desa Blulukan Kecamatan Colomadu Kabupaten Karanganyar. Skripsi tidak diterbitkan. Surakarta: Universitas Muhammadiyah Surakarta.

Gunanthi, N. W., \& Diniari, N. (2016). Prevalensi dan gambaran gangguan tidur berdasarkan karakteristik mahasiswa semester i program studi pendidikan dokter fakultas kedokteran universitas udayana tahun 2015. E-Journal Medika, 5(4), 1-9. https://ojs.unud.ac.id/index.php/eum/article/view/ 19967.

Hapsari, A., \& Kurniawan, A. (2019). Efektivitas cognitive behavior therapy (cbt) untuk meningkatkan kualitas tidur penderita gejala insomnia usia dewasa awal. Jurnal Ilmu Keluarga dan Konsumen, 12(3), 223-235. http://dx.doi.org/ 10.24156/jikk.2019.12.3.223

Hardani, P. T., \& Putri, Y. S. (2016). Relaksasi otot progresif dalam mengatasi insomnia pada lansia di panti tresna werdha. Jurnal Keperawatan Jiwa, 4(1), 40-44. https://doi. org/10.26714/jkj.4.1.2016.40-44 
Hubbling, A., Spong, M. R., Kreitzer, M. J., \& Gross, C. R. (2014). How mindfulness changed my sleep: Focus groups with chronic insomnia patients. BMC Complementary and Alternative Medicine, 14(50), 1-11. https://doi.org/10.1186/ 1472-6882-14-50

Kabat-Zinn, J. (2012). Beginner's mind. Canada: Sounds True Inc.

Kabat-Zinn, J. (2013). Full catastrophe living. New York: Bantam Books.

Keng, S.-L., Smoski, M. J., \& Robins, C. J. (2011). Effects of mindfulness on psychological health: A review of empirical studies. Elsevier, 3(1), 1041-1056. https://doi.org/10.1016/j. cpr.2011.04.006.

Khoury, B., Lecomte, T., Fortin,G., Masse,M., Therien, P., Bouchard,V.,et al. (2013). Mindfulness-based therapy: A comprehensive metaanalysis. Clinical Psychology Review, 33(6), 763-771. http://10.1016/j.cpr.2013.05.005

Larouche, M., Lorrain, D., Cote, G., \& Belisle, D. (2015). Evaluation of the effectiveness of mindfulness based cognitive therapy to treat chronic insomnia. Elsevier Masson, 6(5), 115-123. http://dx.doi.org/10.1016/j.erap.2015.03.002

Latipun. (2015). Psikologi eksperimen. Malang: UMM Press.

McDaniel, C., \& Gates, R. (2015). Marketing research (10th ed.). USA: Wiley \& Sons, Inc.

McMain, S., Newman, M. G., Segal, Z. V., \& Derubeis, R. J. (2015). Cognitive behavioral therapy: Current status and future research directions. Psychotherapy Research, 1-9. http://dx.doi.org/10.1080/10503307.2014.1002440

Munazilah, \& Hasanat, N. U. (2018). Program mindfulness based stress reduction untuk menurunkan kecemasan pada individu dengan penyakit jantung koroner. GAMA JPP, 4(1), 22-32. http://dx.doi.org/10.22146/gamajpp.45346

Nashori, F., \& Wulandari, E. D. (2017). Psikologi tidur: dari kualitas tidur hingga insomnia. Yogyakarta: Universitas Islam Indonesia.

Nashori, F., Hidayat, B., Lukman, Putra, A. A., Kusprayogi, Y., \& Diana, R. R. (2020). Decreasing Insomnia among College Students with Dyspepsia gastritis: the role of Islamic-Cognitive behavioral therapy. Talent Developmental \& Excellence, 12(1), 4436-4451. https://www.iratde.com/ index.php/jtde/article/view/1458

Nashori, F., Nugraha, S. P., \& Wulandari, E. D. (2019). Insomnia-cognitive behavior therapy to improve the subjective well-being of university students. Psychology And Education: An Interdiscplinary Journal, 56(2), 10-18. https: //www.researchgate.net/publication/349669178_InsomniaCognitive_Behavior_Therapy_to_Improve_the_Subjective_ Well-Being_of_University_Students

Nasution, I. N. (2017). Hubungan kontrol diri dengan perilaku sulit tidur (insomnia). Psychopolitan, 1(1), 40-48. http:// jurnal.univrab.ac.id/index.php/psi/article/view/332.

National Institutes of Health. (2011). National institutes of health sleep disorders research plan. Retrived from https://www.nhlbi.nih.gov/files/docs/ncsdr/ 201101011NationalSleepDisordersResearchPlanDHHSPublication11- 7820.pdf

Nevid, J. S., Rathus, S. A., \& Greene, B. (2018). Abnormal psychology in a changing world. Jakarta: Penerbit Erlangga.

Nurdin, M. A., Arsin, A. A., \& Thaha, R. M. (2018). Kualitas hidup penderita insomnia pada mahasiswa. Jurnal MKMI, 14(2), 128-138. http://dx.doi.org/10.30597/mkmi. v14i1.3464

Ong, J. C., \& Smith, C. E. (2017). Using mindfulness for the treatment of insomnia. Current sleep medicine reports, 3(2), 57-65. https://doi.org/10.1007/s40675-017-0068-1

Pillay, K., \& Eagle, Gillian. (2019). The case for mindfulness interventions for traumatic stress in high violence, low resource settings. Current Psychology, 32(2). 1-15. https: //doi.org/10.1007/s12144-019-00177-1

Premani, N. T., Widyadharma, P. E., Utami, D. I., \& Budiarsa, I. (2017). Insomnia berkolerasi dengan terganggunya kualitas hidup personil militer di lingkungan makesdam ix/ Udayana. Medicina, 48(3), 206-210. http://10.15562/Medicina.v48i3. 160

Salbiah, Nurul A. (2018, Maret 12). Indonesia tempati angka tertinggi insomnia di asia, apa penyebabnya?. https://www.jawapos.com/kesehatan/health-issues/12/03/ 2018/indonesia-tempati-angka-tertinggi-insomnia-di-asiaapa-penyebabnya/.

Santoso, S. (2018). Menguasai statistik dengan SPSS 25. Jakarta: PT Elex Media Komputindo.

Sateia, M. J. (2014). International classification of sleep disorderthird edition. Contemporary Reviews in Sleep Medicine, 146(5), 1387-1394. https://doi.org/10.1378/chest.14-0970

Sathivel, D., \& Setyawati, L. (2017). Prevalensi insomnia pada mahasiswa fakultas kedokteran universitas Udayana. Intisari Sains Medis, 8(2), 87-92. https://doi.org/10.1556/ism.v8i2. 119

Satrio, Y., Wilson, \& Kahtan, M. I. (2018). Perbedaan kejadian insomnia pada mahasiswa tingkat pertama dan akhir. Jurnal Cerrebellum, 4(1), 1016-1023. https://jurnal.untan.ac. id/index.php/jfk/article/view/29451.

Shapiro, S. L., \& Carlson, L. E. (2017). The art of science of mindfulness. Washington DC: American Psychology Association.

Susanti, L. (2015). Faktor-faktor yang mempengaruhi kejadian insomnia di Poliklinik Saraf RS dr. M. Djamil Padang. Jurnal Kesehatan Andalas, 4(3), 951-956.https://doi.org/10.25077/ jka.v4i3.391

Syahrum, \& Salim. (2012). Metodologi penelitian kuantitatif. Bandung: Citapustaka Media.

Taylor, D. J., Gardner, C. E., Bramoweth, A. D., Williams, J. M., Roane, B. M., Grieser, E. A., \& Tatum, J. I. (2011). Insomnia and Mental Health in College Student. Behavioral Sleep Mediciene, 9(2),107-16. https://doi.org/10.1080/15402002. 2011.557992 
Vinny, Patricia E. (2014). Modul teknik mindfulness. 1-50. Tesis Magister Profesi. Universitas Mercu Buana Yogyakarta. Retrieved from https://www.academia.edu/39099544/ modul_teknik_mindfulness_disusun_oleh_patricia_elfira_ vinny_11091018_program_pasca_sarjana_universitas_mercu_ buana_yogyakarta_magister_psikologi_profesi_2014.

Waliyanti, E., \& Pratiwi, W. (2017). Hubungan derajat insomnia dengan konsentrasi belajar mahasiswa program studi ilmu keperawatan di Yogyakarta. Indonesian Journal of Nursing Practices, 1(2), 9-15. https://doi.org/10.18196/ijnp.1256

Wang, X., Li, P., Pan, C., Dai, L., Wu, Y., \& Deng, Y. (2019). The effect of mind-body therapies on insomnia: A systematic review and meta-analysis. Evidence-Based Complementary and Alternative Medicine, 1-17. https://doi. org/10.1155/2019/9359807 